\title{
Technical documentation management with the use of the Access program
}

\section{ZBIGNIEW KRZYSIAK GRZEGORZ BARTNIK ANNA PECYNA WALDEMAR SAMOCIUK *}

The paper presents the concept of using the capabilities of Microsoft Access to manage and archive technical documentation made in the CAD systems (e.g. AutoCAD). An original application was created in the Access program for the design documentation of a rotary cleaning device prototype. It has been shown that such an application can be used to organize and view drawings without the need to use expensive commercial programs to manage drawing files.

KEYWORDS: technical documentation, drawings management, Access database, rotary cleaning device

The greatest advantages of electronic documentation created in computer aided design (CAD) systems are the ease of processing and memorizing project data and drawings $[3,6]$. Storing a large number of paper drawings or storing many data in a conventional manner is troublesome. For these reasons, engineering knowledge database systems are created [7].

In the era of universal computerization, the possession of technical documentation in electronic form is indispensable the information can be quickly sent by e-mail. Such document flow requires, among others contemporary concurrent design.

In the design process, it is very important to manage the documentation in the form of electronic files. For this purpose, commercially available specialist programs are used, eg Autodesk Revit. For economic reasons, their use is justified only in the case of professional, large projects. With smaller or one-off projects it is unprofitable. For this reason, an original concept was developed to use the Access program, which is part of the basic MS Office package for managing drawing files [5]. The aim of the authors was to demonstrate the usefulness of Access for archiving technical documentation and drawing file files on the example of rotating prototype of a cleaning device.

\footnotetext{
* Dr hab. inż. Zbigniew Krzysiak (zbigniew.krzysiak@wp.pl), dr inż. Grzegorz Bartnik (grzegorz.bartnik@up.lublin.pl), dr inż. Anna Pecyna (anna.pecyna@up.lublin.pl), dr inż. Waldemar Samociuk (waldemar. samociuk@up.lublin.pl) - Uniwersytet Przyrodniczy w Lublinie
}

\section{Zarządzanie dokumentacją techniczną z wykorzystaniem programu Access}

\section{Characteristics of the Access program}

Access is a database management system DBMS (database management system). It allows you to create and administer databases. Access belongs to relational database management systems, because individual tables can be interrelated $[1,5]$.

Access allows you to manage all the unnecessary information using a single database file [1, 8, 9]. In such a file, you can divide data into separate parts, called tables. In real time tables can be read only with the data that is needed. In this way, the information contained in the database is not loaded simultaneously, which does not burden the computer's memory.

Electronic forms are used to view, add and update data in tables, and queries - to search and download only those data that are currently necessary. Reports are helpful in analyzing and printing data in a specific layout. Although all database objects are in one file, you can import and export individual tables.

Due to the Access program, a compact documentation is obtained, which can be sent electronically directly to the recipient or placed on the server for download by authorized persons.

An important function is to create backups. Data compression, in turn, saves space, and internet - immediate data transmission.

Database management systems (SZBD) greatly facilitate the archiving of documents, which improves the functioning of the company or organization. Such systems provide access to data and the ability to update data at any time. In the databases, all information is systematized and organized, so one does not waste time browsing through the paper documentation. With a few clicks, the user quickly finds what he is interested in.

An important advantage of the Access database is the online opening of files (drawings or photographs) from other programs, e.g. AutoCAD. The user thus has direct access to the data contained in the source files and the possibility of creating interactive technical documentation. 


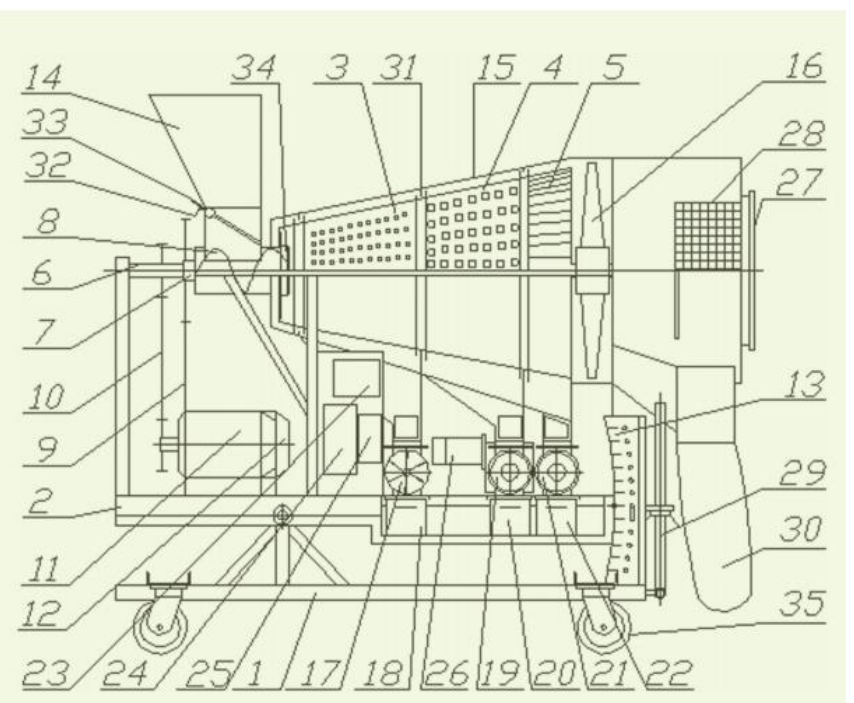

Fig. 1. Scheme of a stationary, rotary cleaning device: 1 - fixed frame, 2 - moving frame, 3 - fine contamination segment, 4 - fine grain segment, 5 - grain segment, 6 - fan drive shaft, 7 - shaft driving sieve drum, 8 - feeding screw, 9 - chain transmission, 10 belt transmission, 11 - electric motor for fan drive, 12 - electric motor for the sieve drum drive, 13 - sieve drum inclination indicator 14 - hopper , 15 - housing, 16 - fan, 17 - rotary valve segment of fine debris, 18 - small impurities tank, 19 - fine grain rotary valve, 20 - fine grain tank, 21 - rotary valve rotating, 22 - grain tank, 23 control switch arrangement, 24 - sieve drum drive control system, 25 - fan drive control system, 26 - moto-reducer to drive rotary valves, 27 - screen of the chaff shell, 28 - air filtration system, 29 adjusting screw, 30 - chaff outlet tank (sack), 31 - labyrinth seal, 33 - bolt closing the mixture outlet, 33 - regulating slide the exit aperture of the mixture, 34 - sealing collar, 35 - running wheel

\section{Technical documentation management}

In the management of technical documentation, it is extremely important to archive drawing files. Archiving is the process of performing an electronic copy of data, including both data created and stored by the user, aimed at securing the information before losing it.

The key element of effective data management is the efficient access to documentation [8]. When the database is placed on the network and access to it is shared by many users, then the management also includes issues related to information security (including limiting the risk of unauthorized access) and the convenience of using them and reducing the space needed to store documents.

Currently, there are many programs on the market for professional drawing management. Unfortunately, they are expensive, and they usually require additional training to handle them.

A useful and easily available program for creating, editing and updating relational databases is Access [1, 5]. The program allows you to adjust the database to the needs of the user and other cooperating programs. Therefore, it was used to create a technical documentation database for the cleaning device [2, 4].

\section{Description of a conical rotary cleaning device}

The prototype of the rotating cleaning device was created at the University of Life Sciences in Lublin (fig. 1).

This device is a complex cereal grain cleaner whose construction is described in detail in previous publications $[2,4]$.

\section{Description of the application for managing technical} documentation

In MS Access 2003 PL, a reference database called "Technical documentation of the cleaning device" was created containing such information about each figure as its:

- number,

- name,

- image.

The image can take the form of a technical drawing made in AutoCAD.

The advantage of the application is that the user can directly open the image from the database and then read all the information that interests him. In addition, photographs have been included in the database, which helps find the right elements for people who do not know the technical drawing.

After starting the application, the control panel is loaded (fig. 2).

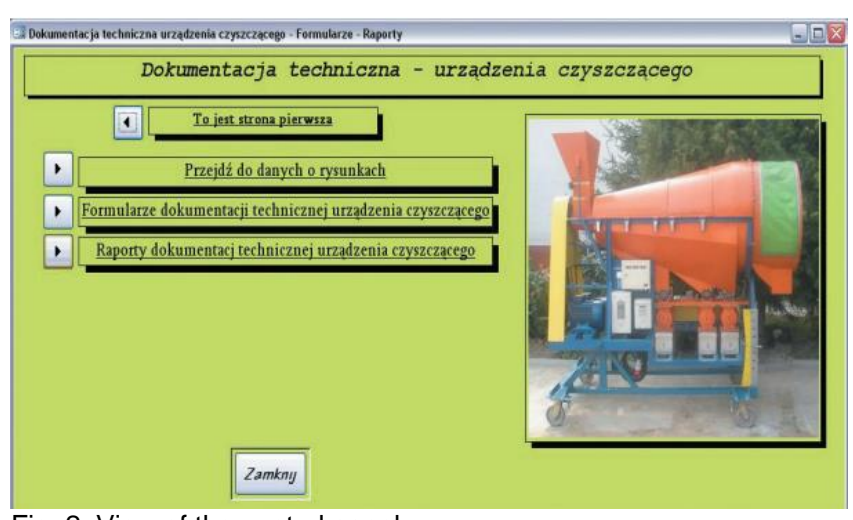

Fig. 2. View of the control panel

It is an extensive menu managing forms and reports. The control panel is treated as a main form. The control panel page includes:

- title of the base,

- photograph of the device,

- four buttons.

The first button is not active because it is used to return to previous pages. By selecting one of the other buttons, the user leaves the main page. To return to it, select the "Go to page one" button.

The next active buttons are: "Go to data on the figures", "Forms of the technical documentation of the cleaning device" and "Reports of the technical documentation of the cleaning device".

Under the "Go to data on drawings" button, there are macros that start selecting queries, which ensures that the relevant information is displayed. They were created on the basis of tables and divided due to the construction of the cleaning device.

The button "Forms of technical documentation of the cleaning device" connects the user with the list of formulas (fig. 3).

After selecting the appropriate form, you should select the button assigned to it, which will switch to the indicated form, e.g. with the subassembly of the main frame (fig. 4). 


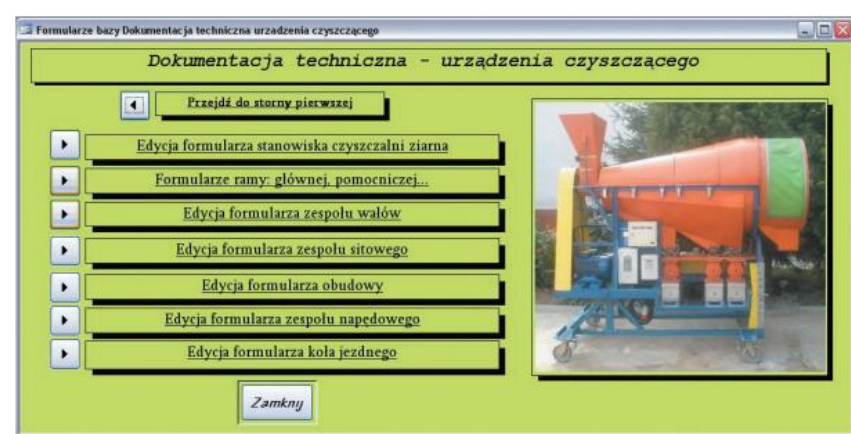

Fig. 3. View of the control panel with forms with assigned buttons

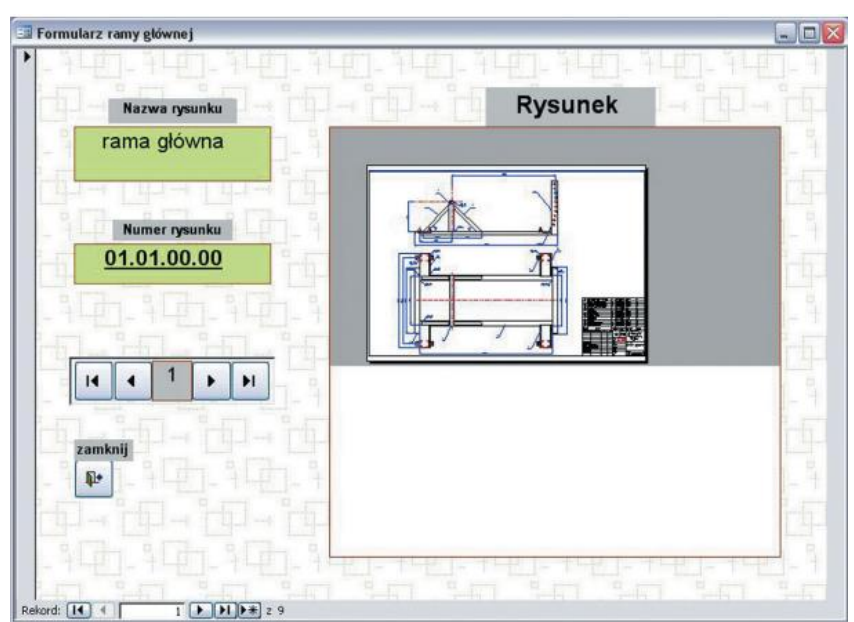

Fig. 4. View of the form with the subassembly of the main frame with the first record open

The last button "Reports of technical documentation of the cleaning device" refers to reports. The list of reports was created just like the list of formulas. After selecting the button of a given report, the indicated report is displayed, e.g. the subassembly of the frame of the main cleaning device (fig. 5).

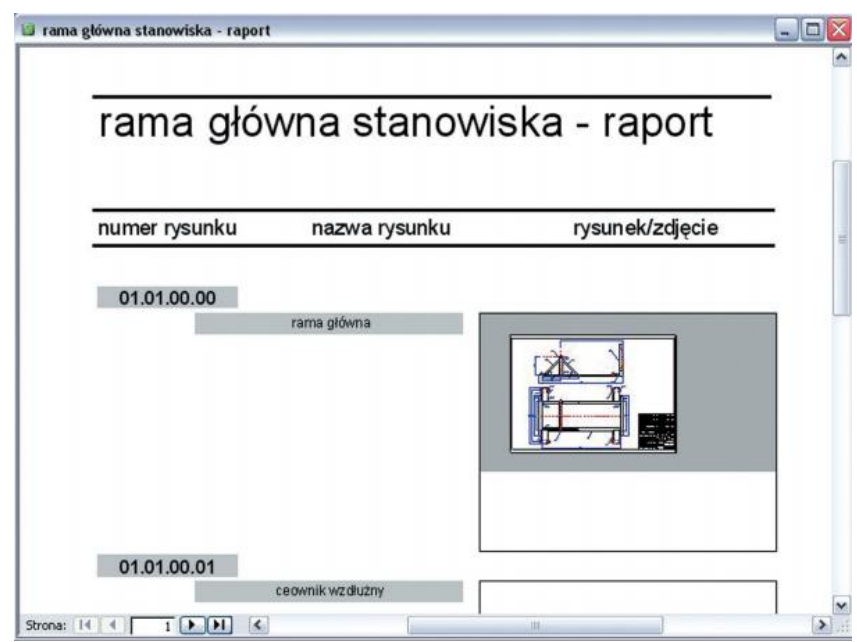

Fig. 5. View of the report with the main frame assembly

Technical documentation of submitted projects, made in one of CAD systems (eg AutoCAD) [3, 6], can be logically arranged in the form of a database, which is managed by means of reports.

The presented database, created in the Access program on the example of technical documentation of a rotary cleaning device, offers the following benefits:

- increases the search speed of drawings or groups of drawings,

- ensures continuous access to the main data form and the ability to print data about drawings,

- allows to edit the data contained in the database,
- enables creating multiple copies of drawings - both in electronic and paper form,

- makes it easy to transfer data on external media,

- enables placing data in a local or global network,

- increases the availability of data due to their placement on a network server,

- ensures low costs of technical documentation storage.

\section{Conclusions}

- Technical documentation of the rotary cleaning device has been included in the developed Access database application. It is at the same time an archive of drawing files and provides an additional copy of the documentation.

- Computer database created in Access enables efficient management of the technical documentation of the rotating cleaning device and its archiving.

- Database in Access allows you to view and search drawings and quickly make changes to them. These changes are made possible by drawing drawings in AutoCAD and saving them as .dwg files stored in the Access database. At any time, you can directly connect to the source program and open a drawing in it. The condition for this connection is to have AutoCAD installed on the same computer as the created application.

- Archiving of the technical documentation of the cleaning device contained in the application may be the basis for the modernization or design of similar devices.

- Due to the arrangement of technical documentation in the form of a database, the risk of losing drawings is reduced. In addition, the documentation in this form is more transparent and easier to use, and above all can be extended with new drawing files.

\section{REFERENCES}

1. Dobson R. „Programowanie MS Access 2000”. Warszawa: RM, 2000. 2. Krzysiak Z. „Budowa nowego rotacyjnego urządzenia czyszczącego”. Mechanik. 2 (2012): pp. 153/14.

3. Krzysiak Z. „Projektowanie 2D w programie AutoCAD”. Warszawa: Wydawnictwo Nauka i Technika, 2016.

4. Krzysiak Z. Urządzenie do czyszczenia ziarna. Wzór użytkowy Ru 65892 (PL 65892 Y1). Urząd Patentowy RP. Warszawa, 2012.

5. Mandrela D., Szeliga M. "Access 2003 PI KURS". Gliwice: Wydawnictwo Helion, 2003.

6. Pikoń A. „AutoCAD 2014 PL”. Gliwice: Wydawnictwo Helion, 2017

7. Pokojski J. „Inżynierskie bazy danych w projektowaniu maszyn”.

Warszawa, 2000

8. Pokorska J. „Tworzenie baz danych i administrowanie bazami”. Gliwice: Wydawnictwo Helion, 2017.

9. Riordan R. „Projektowanie systemów relacyjnych baz danych”. Warszawa: RM, 2002.

Translation of scientific articles, their computer composition and publishing them on the website www.mechanik.media.p by original articles in Polish is a task financed from the funds of the Ministry of Science and Higher Education designated for dissemination of science.

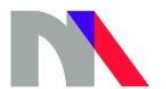

